\title{
SCIENCE EDUCATION AND EVANGELICALS
}

Perceptions of Science Education Among African American and White Evangelicals:

A Texas Case Study

Elizabeth Korver-Glenn, Rice University

Esther Chan, Yale University

Elaine Howard Ecklund, Rice University

Forthcoming, Review of Religious Research 


\section{SCIENCE EDUCATION AND EVANGELICALS}

\section{ABSTRACT}

Evangelicals have been highlighted at the intersections of religion, science, and education, yet little is known about how evangelicals perceive public science education and how these perceptions compare across racial lines. Here we analyze how African American and white evangelicals view science education through 40 in-depth interviews collected from two evangelical congregations in Texas. Without raising the topic of evolution, we find that African American leaders, white leaders, and white laity engaged in faith-based, evolution-contesting discourse, but African American laity rarely framed science education in faith-based ways. For them, science education was often linked to educational resources or was distant from their lived experiences. Our findings clarify disjuncture and overlap among African American and white evangelicals by exploring perceptions that challenge and affirm the public institution of science education in different ways. Our conclusion stresses the need to examine perceptions of science and education among religious subgroups differentiated along social and historical lines.

\section{INTRODUCTION}




\section{SCIENCE EDUCATION AND EVANGELICALS}

Recent research has focused on the complex interaction between science and religion, moving beyond conflict paradigms (author citation; Evans and Evans 2008; Evans 2011; Scheitle 2011a). Yet conflict between religion and science is not unusual in the public sphere, particularly in the context of public education, where key religious and scientific actors 'fight' for intelligent design or for evolution in science education curricula (author citation; Berkman and Plutzer 2010; Binder 2007; Plutzer and Berkman 2008). Highlighted at the nexus of science, religion, and education are evangelicals, who, as part of the broader 'conservative Protestant' category, are a major force forming religious public life and discourse in the U.S. (Emerson and Smith 2000; Hackett and Lindsay 2008; Smith et al. 1998).

However, little research has examined evangelicals' broader perceptions of the relationship of their faith to K-12 public science education, ${ }^{1}$ focusing instead on the influence of evangelical identities and practices on the pursuit of higher education (Beyerlein 2004), educational attainment (Darnell and Sherkat 1997; Glass and Jacobs 2005; Pew Forum 2009; Portraits of American Life Study 2006), and majors chosen at the undergraduate level (Scheitle 2011a). Such analyses demonstrate the relationships that exist among religious groups and science, but do not provide insight into the perceptions underpinning these relationships. Noting that science education functions as the institutionalized producer and disseminator of basic scientific knowledge in the U.S., we highlight its salience in examining the relationship among science, religion, and education and address this gap in the literature. Further, we note that previous research has rarely differentiated between white and African American evangelicals (see Evans 2011 for an exception), despite the historic and current differences that distinguish these groups religiously and in their experience of science and education (Corbie-Smith 1999; Paul 1998).

\footnotetext{
${ }^{1}$ Hereafter, 'K-12 public science education' will be referred to as 'science education'.
} 


\section{SCIENCE EDUCATION AND EVANGELICALS}

Without introducing the topic of evolution, we ask how African American and white evangelicals in a large Texas city compare in their views of science education. In-depth interviews with 40 congregants, 20 from a largely white congregation and 20 from a predominantly African American congregation, yielded two broad conceptual frames. We find that white evangelicals focused on the issue of evolution in science education, framing perceptions as faith-based, while African American evangelicals tended to view science education as under-resourced, adequate, or irrelevant, framing perceptions without a religious lens. In addition, we find that the leaders in both the African American and white church relied more heavily than laity on evolution-centered narratives. Our findings show that there are important differences and similarities between African American and white evangelicals, as well as between congregational leaders and laity, suggesting that African American and white evangelicals, leaders and laity, may engage in discourse over science education in diverse and overlapping ways. Overall our findings corroborate and extend research focusing on the distinctive hallmarks of African American and white evangelicalism (Emerson and Smith 2000; Shelton and Emerson 2012) as well as evangelicals' interactions with evolution (Binder 2007) by highlighting the ways in which individuals in these two groups narrate their understandings of science education.

\section{LITERATURE REVIEW}

Evangelicals, Science, and Education

Despite problems associated with measurement and narrow foci, researchers have begun to examine evangelicals' relationships to science (e.g. Evans and Evans 2008; Sherkat 2011), often highlighting the conflicts between the two realms (Binder 2002; Ellison and Musick 1995; Evans 2002; Mulkay 1997), thus reifying the centrality of conflict in understanding their 


\section{SCIENCE EDUCATION AND EVANGELICALS}

relationship. Questioning this dominant paradigm, Evans (2011) demonstrated that there are only minor differences in the degree to which nonreligious people and evangelicals and other conservative religious groups seek out scientific knowledge. Overall, findings from this study indicate that "[evangelicals] are by and large just as knowledgeable about and involved with science as the nonparticipants in religion" (Evans 2011:721), while differences between nonreligious people and evangelicals can be observed most clearly when science and scientists make claims that are seen as opposing important theological claims of evangelicals. That is, when evangelicals perceive that science and scientists have an anti-religious moral agenda, they engage in a struggle "with science over who should influence public morality" (Evans 2011:713).

Other studies have examined how evangelical identity shapes interface with higher education (Darnell and Sherkat 1997; Deckman 2002; Glass and Jacobs 2005). For example, evangelicals, who form approximately 30 percent of the U.S. population (Pew Forum 2008), are just as likely or more likely to pursue higher education compared to any other religious or nonreligious group, with the exception of Jews (Beyerlein 2004). Pentecostals and fundamentalists, on the other hand, are significantly less likely to do so (Beyerlein 2004). Questioning Sherkat's (2011) argument that conservative Protestants ${ }^{2}$ avoid higher education in order to avoid exposure to science, Evans (2011) demonstrated that it is perhaps only specific disciplines within science that evangelicals may avoid at the level of higher education. For example, due to the secular moral agenda evangelicals associate with evolution, they may avoid becoming "evolutionary biologists or cosmologists" (Evans 2011:723). Further, in a recent

\footnotetext{
${ }^{2}$ Evans (2011) includes evangelicals within the broader category of conservative Protestants in his study. Sherkat (2011) generally uses the labels "sectarian Christian" and "fundamentalist" in his article; however, these labels overlap with denominations that are often considered evangelical and with beliefs about the Bible that are also considered evangelical.
} 


\section{SCIENCE EDUCATION AND EVANGELICALS}

longitudinal study of religiosity and spirituality among undergraduates, Scheitle (2011a; 2011b) found that undergraduates in the natural sciences who came from moderate or conservative Protestant denominations experienced less skepticism about religion over time relative to their other-religious or unaffiliated counterparts. Noting that "students in the natural sciences mirror the overall student population when it comes to religious and spiritual changes that occur in the undergraduate years," Scheitle (2011a:133) concludes that education in the natural sciences has little effect on the religious commitment of undergraduates but it could have a selection effect within particular fields. Research on higher education and science notwithstanding, we still know very little about evangelicals' perceptions of science education at the K-12 level broadly speaking, even though this religious subgroup is particularly influential in the U.S.

Evangelicals, as part of the larger 'conservative Protestant' category, are a major force forming public life and discourse in the U.S. context (Ellison and Musick 1995; Hackett and Lindsay 2008). As such, their broad understandings of publically-funded science education are particularly salient to progressives and policy-makers (Binder 2007), who may feel "political animosities and feelings of social distance from people they consider to be right-wing extremists" (555). We therefore examine evangelicals, as an important subgroup within conservative Protestantism, and as distinct from fundamentalists and Pentecostals (Marsden 1991) to more fully understand their views of science education in public schools. Focusing on evangelicals' narratives of science education without introducing evolution specifically will add to broader knowledge in several ways. First, it will help the scholarly community understand the perceptions — which become individual and collective realities (Davies and Harre 1990) — that may influence evangelicals' pursuits of science education after high school (Scheitle 2011a). Further, it will begin to illuminate whether and to what extent evangelicals and progressives 


\section{SCIENCE EDUCATION AND EVANGELICALS}

share and/or contest understandings of science education, as well as the ways evangelicals associate science education broadly with evolution specifically. Additionally, understanding evangelicals' narratives of science education will help to clarify distinctions between subgroups within conservative Protestantism; preliminary research indicates that evangelicals and fundamentalists may view (science) education in very different ways (Darnell and Sherkat 1997; Evans 2011; Sherkat and Darnell 1999). Importantly, we also seek to illuminate differences or similarities between African American and white evangelicals, extending research that highlights how African Americans evangelicals are distinct from or similar to white evangelicals (Shelton and Emerson 2012) by focusing on the public, secular institution of science education.

\section{Differentiating African American and White Evangelicals}

The overarching term "evangelical" has frequently been applied to diverse groups because of the conservative theological beliefs they often share. This broader description has been particularly true of African American and white evangelicals, who uphold and share core evangelical beliefs, such as beliefs in a personal relationship with Jesus and the Bible as the authoritative word of God, which are two hallmarks of evangelical doctrine (Hackett and Lindsay 2008; Lincoln and Mamiya 1990; Marsden 1991; Shelton and Emerson 2012; Smith et. al 1998). Thus, we favor a beliefs-oriented conceptualization of the term 'evangelical,' noting that at least in matters of core belief, African American and white evangelicals are comparable cases. ${ }^{3}$ Concomitantly, we recognize that African American and white evangelicals are divided along key religious, social, and historical lines (Emerson and Smith 2000; Shelton and Emerson 2012). Thus, should we utilize Steensland et al. (2000) and Woodberry et al.'s (2012) classifications, our African American evangelical case would be classified as "Black Protestant."

\footnotetext{
${ }^{3}$ Emerson and Smith (2000) also compare African American and white evangelicals by using a beliefs-oriented conceptualization of "evangelical."
} 


\section{SCIENCE EDUCATION AND EVANGELICALS}

By favoring a beliefs-oriented operationalization of evangelicalism, we highlight the way white and African American Protestants with similar core theological beliefs may differ in their perspectives on the relationship between their faith and science education.

The African American church has a distinct religious culture due to its historical roots as a central part of African American life from the years before emancipation to the present (Lincoln and Mamiya 1990). The historical and social experiences of African Americans have influenced their doctrinal views, creating a heavy theological emphasis on social issues and economic justice (Steensland et al. 2000). African Americans also have a unique history with science and science education. For example, African Americans endured unjust treatment during the Tuskegee Alabama syphilis trials (Corbie-Smith 1999). The eugenics movement, now understood as pseudo-science, and studies of diseases interpreted through a racial lens, were used to justify discriminatory practices against African Americans (Paul 1998; Gamble 1999). Further, African Americans continue to experience racial discrimination in schools even after the 1954 Brown vs. Board of Education decision (Birzer and Ellis 2006) and there are persistent performance gaps between African Americans and whites in various subjects (Jencks and Phillips 1998; Lubienski 2002; Johnson and Kritsonis 2006).

Additionally, in recent history it is the white evangelical elite and not African American leaders who have spearheaded religion-science conflicts, specifically the teaching of evolution in public schools (Evans 2011). White evangelical elites, for example, may continue to associate the teaching of evolution as symbolic of their repeated defeats in struggling against science progressives and evolution since the Scopes trial of 1925 (Binder 2007). Conversely, African Americans have historically been marginalized in the American context and thus may be more focused on fighting for equal education more broadly (Binder 2007) without focusing on 


\section{SCIENCE EDUCATION AND EVANGELICALS}

specific educational topics. On the other hand, there may be a class divide or other divides emerging within the African American evangelical community (Brown and Brown 2003; also see Hyra 2006) that could influence the extent to which more or less educated African Americans or those more influenced by white evangelicalism are concerned with religion, science, and education conflicts. Given the lack of research on these dynamics within the literature, as well as the potential areas of divergence and overlap within African American and white evangelical groups, we argue for the need to consider more carefully the intergroup and intragroup boundaries that may exist along racial and religious lines.

\section{METHODOLOGY}

In order to examine African American and white evangelicals' narratives of science education, we use data collected as a part a larger national study that examines the way members from a variety of religious traditions view the science-faith interface. The study, which collected qualitative interview data and did not oversample African American congregations, was conducted in cities in the South, Midwest, and Northeast regions of the U.S. We specifically utilize data on two Evangelical Baptist congregations located in a large Texas city; these congregations were intentionally selected to catalyze comparison of congregations that differ along racial and socioeconomic lines. The science-faith interface has been and continues to be relevant to Texas's history with a number of controversies over intelligent design and evolution

(e.g. the resignation of the director of the science curriculum for the Texas Education Agency in 2007); further, many religious groups — particularly evangelical Christians — have participated in these debates (Blumenthal 2007). We chose evangelical churches because of the size of this population within the U.S. and corresponding influence on political policies (Hackett and Lindsay 2008; Smidt 2013), and especially for their potential influence on science education 


\section{SCIENCE EDUCATION AND EVANGELICALS}

policy (Ellison and Musick 1995). Baptists are a significant group within the overall evangelical population, comprising $41 \%$ of Evangelicals (Pew Survey 2008). Likewise, nearly two-thirds (64\%) of historically African American Protestant churches are Baptists (Pew Survey 2008). Given their relative sizes in the Evangelical and historically Protestant churches, Baptists have the potential to influence public discourse on science and education.

The first congregation in our study is a predominantly white Southern Baptist congregation that has an approximate attendance of 5,000 individuals every Sunday. The congregation is also located in area with a mean income of $\$ 197,090$ and attendees are middle class and upper class ${ }^{4}$. This congregation can be classified as a mega-church using Thumma's (2001) definition of having a weekly attendance of over 2,000 members. Mega-churches tend to cluster in the Bible belt with 40 percent found in the South (Thumma 2001). In Texas alone there are 206 mega-churches whose average attendance range from 1,800 to 43,500 (Hartford Institute for Religion Research). Around 79.5 percent of all mega-church attendees are white, followed by 10.5 percent black, and $48 \%$ of mega-churches have core evangelical beliefs (Thumma 2001). The white congregation in our study reflects these broader trends.

The other congregation is an African American Baptist congregation with approximately 175 attendees ${ }^{5}$. Its congregants tended to be of lower socio-economic status and have less education. The congregation itself is located in an area where the mean income is $\$ 40,343$ (U.S. Census 2010). Although smaller in size and of lower socio-economic status, the congregation provided a large number of social services and community programs, including an educational program for children that focused on math and reading but also incorporated science

\footnotetext{
${ }^{4}$ Congregational class composition was obtained from interviews with religious leaders (SBC_Int4RL, 06/22/11, SBC_Int3RL, 06/08/11) and participant observations.

5 Approximate congregational attendance was taken from interview with religious leaders (AAB_Int19RL, 08/11/11) and participant observations.
} 


\section{SCIENCE EDUCATION AND EVANGELICALS}

education. While there has been a recent trend among African American churches towards megachurches, the majority of African American churches in the United States have around 100-500 regular attendees and have historically provided a broad range of social services (Mamiya 2006). The African American evangelical congregation in our study is thus representative in its reflection of both the historic and current composition of many African American churches. Similarly to the white Baptist church, the African American Baptist church affirms core evangelical beliefs, such as emphasis on the authority of the Bible as the Word of God and a personal relationship with Jesus; however, the African American congregation is Pentecostal and thus differs from the white congregation in terms of its emphasis on the theology of the Holy Spirit. While we acknowledge that these specific beliefs vary across our two congregations, we also note that these differences are reflected across Evangelicalism more broadly. Ultimately, our selected cases allow us to elucidate important differences that may exist along racial and socioeconomic lines within Evangelicalism, even as core beliefs are generally shared (author citation).

Over the course of a year, a total of 55 participant observations were completed at the two churches. Researchers, including the senior author and junior researchers, conducted a total of 30 observations at the African American church, attending a variety of Sunday services, Bible studies, and workshops. A total of 25 observations were completed at the white congregation. Through these interactions, researchers were able to establish relationships for interviews and a total of 40 interviews were conducted using a snowball sampling method. Researchers interviewed nine men and eleven women in the African American congregation. Four of these respondents were pastors or ministers in the congregation. Respondent ages ranged from 22 to 79. The average age of the respondents is 54 , which roughly represents the age demographic of the congregation. In the white congregation, six women and fourteen men were interviewed. Five 


\section{SCIENCE EDUCATION AND EVANGELICALS}

of these respondents were in leadership positions, such as youth ministry, college ministry, and pastoral positions. Respondent ages ranged from 19 to 76 . The average age of the respondents is 36, also reflecting the age demographic of the white congregation. Likewise, this is representative of broader evangelical churches in which 39 percent of attendees fall between the ages of thirty to forty-nine (Pew Forum 2010). For both congregations, we use occupation and educational attainment ${ }^{6}$ as proxies for class.

While our interview guide ${ }^{7}$ covers a number of topics related to the religion and science interface, such as views on conflict between religion and science, understandings of evolution, stem cell research, and human genetic reproductive technologies, the majority of the data analyzed was drawn from the following question: 'What do you think about the state of primary and secondary science education in the US?' Holding in tension sensitivity to respondents' educational backgrounds and our topic of interest, interviewers were free to reword the above question in less formal language. Further, we do not assume that because respondents are religious, they will automatically use religious language in explaining their views of science education in the U.S. By asking about respondents' opinions of science education without connecting religion or religiously-charged topics (e.g. evolution) to this question, we were able to see whether or not respondents would draw on religiously-infused language to describe science education. Additionally, the relationship among religion, science, and education often came up in the interviews prior to this question as participants were asked questions about the religion and science interface more broadly, demonstrating its heightened salience for these

\footnotetext{
${ }^{6}$ Information on educational attainment was not available for all respondents. In the cases where this information was missing, we rely on respondent occupation to provide an estimate of class. Of those known, roughly half of those in the African American congregation had a bachelor's degree, while 95\% of the white congregation had a bachelor's degree or higher. All leaders at the African American congregation had a bachelor's degree or higher, while $30 \%$ of laity respondents had a bachelor's degree. All but one leader at the white congregation had a bachelor's degree or higher. Information regarding education attainment was not available for that one white leader. All but one laity respondent had a bachelor's degree.

${ }^{7}$ The interview guide is available upon request.
} 


\section{SCIENCE EDUCATION AND EVANGELICALS}

respondents - most of whom were white. All interviews were in-person. Interviews ranged from 40 minutes to two and a half hours and lasted an average of 74 minutes. Interviews were transcribed and coded for themes related to our research question. Each congregation was coded separately and then we compared each congregation across these themes. While we recognize that findings yielded from this study are not generalizable to broader white or African American evangelical congregations, the selected cases in our study provide insight into some of the ways religion, race, and education may intersect.

We employed a modified inductive process to gain insight into the narratives used by black and white evangelicals to explain their views of science. Such a process does not begin with hypothesis testing, but begins with nascent ideas related to an understudied topic. Rather than conducting a study to confirm or disprove hypotheses, the modified inductive process allows themes to emerge as the study progresses. We examine discursive narratives, which contest, create, and reproduce social and psychological knowledge and realities (Davies and Harre 1990) "at the disciplinary, the cultural and the small group level" (45). Importantly, these discourses influence individuals' and groups' beliefs and actions (Thomas and Thomas 1928). If African American and white evangelicals employ different narratives in understanding science education, this may suggest that they will have different modes of engagement with science and faith issues. And if these two groups explain science education similarly, this may give us insight into shared tensions within racially-divided evangelicalism. Through semi-structured in-depth interviews we were able to examine how these two congregations compared in their narratives of science education broadly speaking.

\section{FINDINGS}




\section{SCIENCE EDUCATION AND EVANGELICALS}

Overall, our findings indicate key distinctions between African American and white evangelicals, as well as between church leaders and laity. Within these two congregations, two broad ways of framing science education emerged from respondents' narratives. The first group, which included white leaders and laity as well as African American leaders, framed their responses to science education in faith-based terms, highlighting evolution as particularly problematic. The second group, which primarily included African American laity, described science education in secular terms, viewing it as under-resourced, adequate, or irrelevant. We now turn to examining these two categories, paying particular attention to the ways race, class, as well as position of authority within the church intersect in respondents' narrative perceptions.

-Insert Figure 1 about here-

\section{Faith-Based Narratives: The Problem of Evolution}

We found that many of the respondents in both congregations perceive science education as necessary but problematic because religious perspectives on evolution are not invited in public school classrooms. Thus, respondents contested a specific scientific theory and not necessarily the application of science to, for example, medicine or technology. Further, white and African American evangelical leaders in our study relied on this understanding of science education far more than African American and white lay evangelicals.

All six of the religious leaders we interviewed in the largely white evangelical church discussed the state of science education in the U.S. with references to evolution or creationism. One 45 year-old white youth minister $^{8}$ explained,

I think that most parents see public school science education as a necessary evil. Not that they're opposed. I mean, I think they very much want their kids to be involved in physics and chemistry and biology and those types of science disciplines. But I

\footnotetext{
${ }^{8}$ SBC_Int3RL, 06/08/11
} 


\section{SCIENCE EDUCATION AND EVANGELICALS}

think...it is the topic of evolution that most gives them pause in having their kid in that type of environment.

Similarly, a 29 year-old leader of the youth ministry ${ }^{9}$ explained

Our students are being pushed way harder than I ever was in science...the age they're starting to learn chemistry and biology and physics...is great...I just hate how emphatically they talk about evolution. And I hate that our students get that rammed down their throat almost every day, when they sit in their science classes...I wish [teachers would] lay out the options for them, rather than saying, 'This is what it is, if you don't believe that you're an idiot.'

For these respondents, science education is seen as a valuable and worthy pursuit; however, they felt that evolution was being forced upon students as the only right way to view the development of life on earth. Science education is necessary, but evolution as part of the public school curriculum is disputed. One 37 year-old white male leader ${ }^{10}$ even went as far as to suggest that individuals who did not want evolution taught in public schools should be able to retract tax dollars to send their children to schools that teach creation.

Similar to the leaders at the white congregation, leaders of the African American church often highlighted evolution in their discussion of science education (three out of four African American leaders fell into this category). The head pastor ${ }^{11}$ of the African American church, a 60 year-old male, thought that science education was important as a "means to end the suffering that they felt or their parents felt," but did not approve of teaching topics like stem-cell research and evolution as necessary components of science education. Another leader at the

\footnotetext{
${ }^{9}$ SBC_Int4RL, 06/22/11

${ }^{10} \mathrm{SBC}$ Int2RL

${ }^{11}$ AAB_Int16_RL, 07/28/11
} 


\section{SCIENCE EDUCATION AND EVANGELICALS}

African American congregation, a male assistant pastor, ${ }^{12}$ was in some ways suspicious of the general content of education but overall supported education; science education was no more important than other aspects of education. Specifically with respect to science education, he claimed that both evangelicals who interpret biblical creation accounts literally and scientists who assert evolution are making claims based on faith;

[T]here are people within the scientific field that think that they can talk billions of years ago as if they were there to watch it, and see it all happen. And they speak as those people who say, well, actually this thing happened six thousand years ago sound less intelligent than they do.... when we talk about things that are beyond our ability to know, we've entered into the faith realm.

For him, it followed that there should be room for both alternative creation accounts and evolution in public science education.

A subset of lay congregants $(n=8)$ at the white evangelical church also viewed science education as a 'necessary evil.' A 50 year-old white male working in IT $^{13}$ described science education as having a naturalistic bias. Even though he had enrolled his children in a private Christian high school, he explained "I look at the perspective that they take and it's a purely naturalistic perspective ... there's a definite bias in the education and academic community...that filters down into the high school level and below, because they're the ones who write the books." Even in a Christian high school, he saw that a naturalistic bias permeated science education because the irreligious academic community had a monopoly on the production of science knowledge. One 24 year-old man in the military ${ }^{14}$ saw the necessity of science education and scientific findings in his career, explaining, "Oh man, science is what makes my job possible.

\footnotetext{
12 AAB_Int19_RL, 08/11/11

${ }^{13}$ SBC_Int $14,12 / 02 / 11$

${ }^{14}$ SBC_Int5, 07/05/11
} 


\section{SCIENCE EDUCATION AND EVANGELICALS}

Science is what keeps me in the air, and not crashing into the ground... That's what allows my helicopter to fly, so I think about that really on a very- it's what keeps me alive." While he saw the benefits of science education and discussed enjoying learning about aerodynamics and physics as an undergraduate, he also perceived the rejection of creationism in schools as problematic. Instead, this respondent felt creationism and evolution should be taught together. Meanwhile, only one of the lay congregants at the African American church specifically introduced the topic of evolution as problematic within public science education; at the same time, this 57 -year old retired female ${ }^{15}$ also affirmed the value of science education more broadly, explaining,

There were so many more sessions...preparing for the math [standardized test], and the social studies [standardized test], the English [standardized test], but like science was like a stepchild. And either they're going to know it or they're not going to know it. So I feel that...they need to upgrade, update, up the expectations. Because after all, the children are our future.

This same respondent went on to suggest that because students "are being taught one thing at the church, then they're taught another thing in the school" regarding evolution, "there should be a meeting of the minds between the scientists and the religious leaders, as they present these ideas to the children." In addition to this respondent, the white evangelical leaders and subsets of the white laity and African American leadership suggested exchanging and/or teaching diverse perspectives as a way to improve the quality of science education.

\section{Secular Narratives: Resources and Relevance}

As we have seen, several leaders of the African American congregation and the white congregation and many white laity strongly objected to the presence of evolution in the

\footnotetext{
${ }^{15}$ AAB_Int3, 06/24/11
} 


\section{SCIENCE EDUCATION AND EVANGELICALS}

classroom. But in contrast to these evangelicals, several lay congregants, primarily African American $(\mathrm{n}=11)$, often challenged science education for other reasons. One of the narratives this group employed was a criticism of a lack of educational resources. ${ }^{16}$ Such explanations did not rely on faith-based arguments to communicate deficiencies in science education. This contrasts with the leaders who tended to draw on religious narratives to describe their discontent with science education. For example, one 66 year-old retired African American congregant ${ }^{17}$ saw science education as an essential component of improving life chances for children:

Our children are not being taught good enough to grow up to be scientists....If our schools were better and our schools would demand better teachers- the children...could be able to thrive and be better people....

When asked how science education could be improved, she replied: "We have to have better teachers. In order for us to have the astronauts we have they have to have good teachers." Also at the African American church, a 60 year-old printing company employee ${ }^{18}$ viewed science $^{2}$ education in the U.S. as adequate but lagging behind other countries. He thought that encouraging more science projects and fairs as well as providing more incentives for children to learn science would help improve the overall outcomes of science education. Several other African American congregants echoed these responses, indicating that children are not receiving enough science education and that the science education they are receiving is deficient in some way. ${ }^{19}$ They framed science education in the U.S. as problematic while affirming its importance, but did not link perceived resource-related problems to any faith-based concerns.

\footnotetext{
${ }^{16}$ Five African American lay congregants viewed science education as under-resourced. Only one white lay congregant viewed science education as under-resourced.

${ }^{17}$ AAB_Int7, 07/14/11

18 AAB_Int $11,07 / 24 / 11$

${ }^{19}$ AAB_Int1,06/15/11; AAB_Int3, 06/24/11; AAB_Int8, 07/17/11; AAB_Int9, 07/24/11; AAB_Int10, 07/24/11; AAB_Int13, 07/28/13; AAB_Int18, 08/10/11
} 


\section{SCIENCE EDUCATION AND EVANGELICALS}

Other secular narratives emerged from our respondents, including those who saw public science education as adequate, with no real need for change, or those who expressed unfamiliarity with science education and did not offer an opinion beyond this. These secular responses came from both African American laity $(n=6)$ and a subset of white laity $(n=5)$. Despite the negative historical experiences African Americans more broadly have had with science and education, these African American evangelicals tended not to have negative opinions - religious or otherwise - about public science education. This suggests that for these respondents, science education or contested topics like evolution are not a part of the everyday experience of their religious faith, indicating distance from many of the white evangelicals and African American evangelical leaders in our study. For example, a 64-year old retired African

American male, ${ }^{20}$ when asked his opinion about science education, simply said, "I think it's still good." Another congregant at the African American church, a 22-year old female, ${ }^{21}$ expressed a similar sentiment, remarking "I would say it's pretty good. I think science is a big part of education." The church administrator of the African American church, a 42-year old female, was more tentative in her response:

So I'm not really around this so I don't really know... when I came through math, reading, and English were important, now I would venture to say that science is in that category too now. Because there's so many occupations and careers that you could go into in the science arena. So I would venture to say that science is really, really prominent in today- in the schools and things today.

As both of her daughters are now young adults, this respondent was somewhat hesitant to offer an authoritative opinion, but reasoned that science education is probably prominent because of

\footnotetext{
${ }^{20}$ AAB_Int4, 06/26/11

${ }^{21}$ AAB_Int14,07/28/11
} 


\section{SCIENCE EDUCATION AND EVANGELICALS}

the numerous science-related careers now available. One of the white evangelical respondents also expressed sentiments similar to the African American respondents who see science education as good or adequate. A 25-year old male marketing director ${ }^{22}$ responded to critiques he had heard about science education becoming more "liberal" by opining

I think there's just more options out there. Finding more things or discovering more stuff. I think it's definitely changing from what I remember as a kid, and I think the number one issue right now, hearing about recent news, hearing from parents that have kids in school right now, is evolution. Should it be taught and should it not be taught. This respondent went on to agree that children receive enough science education, but also noted that some schools have far fewer resources than other schools, comparing urban and suburban schools. Significantly, this respondent did not express any negativity towards evolution or science education more broadly. While he acknowledged that this is a debate he is aware of, he emphasized that science education is "getting more open-minded" - and also noted that while science education is adequate, there are exceptions.

Other African American congregants explained that they were too far removed from public science education to be able to express an opinion about it. One 71-year old female ${ }^{23}$ responded, “I don't know, because I'm not really enlightened enough on what the state of scientific education is right now. I don't know." Another older female, this time a 79-year old dietician's assistant, ${ }^{24}$ offered a similar admission: "Never really gave it a thought. I don't know." These two women, perhaps because of their age, do not view science education as relevant to their everyday lives, nor do they attempt to offer an opinion based on a distinctly

\footnotetext{
${ }^{22}$ SBC_Int7, 07/27/11

${ }^{23}$ AAB_Int5, 07/06/11

${ }^{24}$ AAB_Int6, 07/08/11
} 


\section{SCIENCE EDUCATION AND EVANGELICALS}

religious framework, as in the case of the 50-year old white male IT specialist ${ }^{25}$ at the white evangelical church, who admitted to not knowing much about science education in the U.S. but nevertheless opined that it had a naturalistic bias. Thus, for this group of respondents, science education is viewed as "pretty good" 26 or as unfamiliar because it does not intersect with their daily lives. For these congregants, as well as those who viewed science education as underresourced, science education is not framed in faith-based terms. In other words, their immediate narrative is framed in secular terms and without reference to evolution, a topic often viewed as a central issue marking evangelicals' relationship to science (Darnell and Sherkat 1997) and education (Berkman and Plutzer 2010; Binder 2007).

\section{CONCLUSION}

Recognizing the strong similarities in core beliefs of both African American and white evangelicals, we explored how these two groups compare in their perceptions of science education. Our study expands the current literature by de-emphasizing contentious topics to examine evangelicals' understandings of science education broadly speaking. In addition, by examining African American and white evangelicals separately, we show that within- and between-group evangelicals are not uniform in their views of science education. We found that white laity and leaders from both the African American and white churches framed science education in the United States as a "necessary evil" more often than their African American lay counterparts. While they viewed science education as beneficial, they often pointed out the teaching of evolution in public schools as a serious problem. Conversely, African American laity, along with a smaller subset of white laity, often perceived science education in secular ways. For example, those who described public science education as under-resourced were more

\footnotetext{
${ }^{25}$ SBC_Int $14,12 / 2 / 2011$

${ }^{26}$ e.g. AAB_Int14, 07/28/11
} 


\section{SCIENCE EDUCATION AND EVANGELICALS}

focused on the pragmatic outcomes of science education, rather than substantive curricula taught in classrooms. That is, African American laity in our sample often viewed science education, if effective, as a 'this-worldly' resource leading to better life chances. This was in contrast to many of the white leaders and laity, who seemed to focus more on the 'other-worldly' and negative effects of what they perceive to be a morally salient, specific science education topic-evolution. Another subset of respondents, primarily from the African American church, saw science education as either adequate or as an unfamiliar topic - one that was not a salient aspect of their lived experience. Importantly, none of these respondents framed science education as related to their evangelical beliefs.

Our findings also revealed distance between the evangelical leaders and laity in our sample with respect to their perceptions of science education. Leaders in both the African American and white evangelical churches emphasized the teaching of evolution as a negative aspect of science education more often than lay members in their respective congregations. This suggests that evangelical leaders, as primary stakeholders within their religious groups, may be more invested than lay evangelicals in the narratives that highlight faith-based conflicts with science education. Regarding the differences between African American leader and lay perceptions of science education specifically, we theorize that these differences may stem from African American leaders' higher levels of theological education and training relative to African American lay theological education (Shelton and Emerson 2012). Higher levels of theological education could have put African American leaders into greater contact with white evangelical theology and perhaps increased the salience of evolution for these respondents. Our findings broaden public and scholarly discourse surrounding religion, science, and public education because they reveal that many lay evangelicals in our sample, African American and white, do 


\section{SCIENCE EDUCATION AND EVANGELICALS}

not frame science education as a faith-related problem. Overall, our respondents viewed science education as necessary and valuable, even as evangelical leaders and some laity contested the content and method of teaching evolution in public science education.

Additionally, our findings show differences and similarities in the ways African American and white evangelicals in our study frame science education. Several white evangelical lay congregants in our study relied more on discourses shaped by the heated debates surrounding evolution curricula in public schools, viewing it as problematic of an otherwise necessary core of education. The reliance on an evolution-informed discourse was present even in the narrative of the young male marketing director, ${ }^{27}$ who referred to the evolution debates in his description of science education but viewed science education expanding in a positive and open-minded way. On the other hand, this evolution-discourse was not part of several white lay members' narratives and was almost completely absent from the interviews with African American lay evangelicals. This was seen in white education professionals' responses, where an emphasis on science education as under-resourced overlapped more with many African American lay narratives than with other white lay narratives. African American lay congregants primarily viewed science education in secular terms: as under-resourced, as adequate, or as an unfamiliar topic not relevant to their daily lives. While not always the case, their responses often indicated deep concern for the educational inequality continuing to have an impact more broadly on some groups of African Americans or, less often, distance from educational issues. In the former case, African American lay respondents at times expressed optimism about the potential

\footnotetext{
${ }^{27}$ SBC_Int7, 07/27/11
} 


\section{SCIENCE EDUCATION AND EVANGELICALS}

of science education's role in promoting social mobility for African American youth, allowing them to leave behind some of the daily strains associated with life in their low-income community. At other times, African American laity expressed a lack of familiarity with public science education as it did not intersect with their lived experience, indicating symbolic and physical distance from this topic. Additionally, these respondents did not draw on faith-based language to decrease this distance; that is, they did not use their theological paradigms and discourses to offer on-the-spot opinions about science education. This finding echoes the historical and social contexts of African American theology, which prioritizes themes such as coping "with suffering associated with everyday trials and tribulations" (Shelton and Emerson 2012:86). For these evangelical respondents, there was no narrative attachment to a symbolic, evolution-versus-creation battle about authority in the public school classroom (Binder 2007). Results indicate that if there is a battle between evolution and creation for evangelicals that it may be primarily an issue for white evangelicals.

For future research, we suggest that scholars continue to examine between- and withingroup similarities and differences within the evangelical community. We suggest that this research focus specifically on perceptions of and participation in public education, rooted in robust treatment of the unique historical contexts of race and class divisions within evangelicalism. The largely white evangelical church in our sample, for example, was also predominantly middle- and upper-middle-class, reflecting higher levels of education and a more empowered social position. On the other hand, respondents at the largely African American evangelical church were predominantly lower- and lower-middle-class, generally reflecting lower levels of education and a less empowered social position. Therefore, future research should further elucidate how class differences might be influential in forming perceptions. 


\section{SCIENCE EDUCATION AND EVANGELICALS}

Despite these race and class differences, many African American and some white lay evangelicals in our sample shared concerns about science education unrelated to the faith-based, evolution-centric narratives of many white and African American leaders and other white laity. Conversely, the white and African American leaders often shared religiously-oriented narratives that distanced them from many of their lay members. In addition, future research should examine how religious leaders and laity may compare in their perceptions of the contentious issues that are most often highlighted in the religion-science-education literature (e.g. evolution and stem cell research). By exploring the nuances in religion-science-education along these different axes, we will be able to more fully understand how evangelical subgroups engage in the discourse surrounding science education in the United States. Additionally, future research should also focus on religious attitudes towards science and education broadly speaking. Continued research in these areas will aid in fostering balanced public policy that does not assume generalized conflict between religious and science-education spheres. Examining broadly across axes and at specific intersections of these axes will avoid missing the mark for certain religious populations - as in the example of our African American and white respondents who were more worried about the provision of textbooks than the specific content of textbooks. It will also avoid transposing a problem in one sphere-for example, white and African American evangelical leaders' strong disapproval of evolution curricula in public science education - into another sphere where the 'problem' is not problematic. This broad-and-narrow approach will thus avoid creating or perpetuating conflict among populations for whom it did not formerly exist; it will also nuance understandings of religion-science conflicts, which may be more or less salient across religious subgroups than heated public debates indicate.

\section{REFERENCES}




\section{SCIENCE EDUCATION AND EVANGELICALS}

Berkman, Michael, and Erik Plutzer. 2010. Evolution, Creationism, and the Battle to Control America's Classrooms. Cambridge: Cambridge University Press.

Beyerlein, Kraig. 2004. "Specifying the Impact of Conservative Protestantism on Educational Attainment." Journal for the Scientific Study of Religion 43(4):505-518.

Binder, Amy. 2002. Contentious Curricula: Afrocentrism and Creationism in American Public Schools. Princeton, NJ: Princeton University Press.

Binder, Amy. 2007. "Gathering Intelligence on Intelligent Design: Where Did It Come From, Where Is It Going, and How Should Progressives Manage It?” American Journal of Education 113(4):549-576.

Birzer, Michael and Richard Ellis. 2006. "Debunking the Myth That All Is Well in the Home of Brown V. Topeka Board of Education: A Study of Perceived Discrimination.” Journal of Black Studies 36(6):798-814.

Blumenthal, Ralph. 2007. "Official Leaves Post as Texas Prepares to Debate Science Education Standards.” New York Times. Retrieved 26 August 2013 (http://www.nytimes.com/2007/12/03/us/03evolution.html?_r=0).

Brown, R. Khari and Ronald E. Brown. 2003. "Faith and Works: Church-Based Social Capital Resources and African American Political Activism.” Social Forces 82(2):617-641.

Corbie-Smith, G. 1999. "The Continuing Legacy of the Tuskegee Syphilis Study: Considerations for Clinical Investigation." American Journal of the Medical Sciences 317(1):5-8.

Darnell, Alfred, and Darren E. Sherkat. 1997. “The Impact of Protestant Fundamentalism on Educational Attainment.” American Sociological Review 62:306-16.

Davies, Bronwyn and Rom Harré. 1990. "Positioning: The Discursive Production of Selves." Journal for the Theory of Social Behavior 20(1):43-63. 


\section{SCIENCE EDUCATION AND EVANGELICALS}

Deckman, Melissa M. 2002. "Holy ABCs! The Impact of Religion on Attitudes About Education Policies." Social Science Quarterly 83:472-87.

Ellison, Christopher G. and Marc A. Musick. 1995. “Conservative Protestantism and Public Opinion Towards Science.” Review of Religious Research 36(3):245-262.

Emerson, Michael O. and Christian Smith. 2000. Divided by Faith: Evangelical Religion and the Problem of Race in America. New York: Oxford University Press.

Evans, John. 2002. Playing God? Human Genetic Engineering and the Rationalization of Public Bioethical Debate. Chicago: University of Chicago Press.

Evans, John. 2011. "Epistemological and Moral Conflict between Religion and Science.” Journal for the Scientific Study of Religion 50(4):707-727.

Evans, John and Michael Evans. 2008. "Religion and Science: Beyond the Epistemological Conflict Narrative." Annual Review of Sociology 34:87-105.

Gamble, V.N. 1999. "Race and the New Genetics: A Historical Perspective.” Pp. 163-185 in The Implications of Genetics for Health Professionals, edited by M. Hager. New York: Josiah Macy Jr. Foundation.

Glass, Jennifer and Jerry Jacobs. 2005. "Childhood Religious Conservatism and Adult Attainment Among Black and White Women.” Social Forces 84:555-79.

Hackett, Conrad D. and Michael Lindsay. 2008. "Measuring Evangelicalism: Consequences of Different Operationalization Strategies." Journal for the Scientific Study of Religion 47: 499-514.

Hartford Institute for Religion Research. "Database of Megachurches in the U.S." http://hirr.hartsem.edu/megachurch/database.html (accessed 31 January 2013). 


\section{SCIENCE EDUCATION AND EVANGELICALS}

Hyra, Derek S. 2006. "Racial Uplift? Intra-Racial Class Conflict and the Economic Revitalization of Harlem and Bronzeville." City \& Community 5(1):71-92.

Jencks, Christopher and Meredith Phillips. 1998. The Black-White Test Score Gap. Washington: Brookings Institution.

Johnson, Clarence and William Allan Kritsonis. 2006. "The National Dilemma of African American Students: Disparities in Mathematics Achievement and Instruction.” National Forum of Applied Educational Research Journal 20(3):1-7.

Lincoln, C. Eric and Lawrence H. Mamiya. 1990. The Black Church in the African American Experience. Duke University Press.

Lubienski, Sarah Theule. 2002. “A Closer Look at Black-White Mathematics Gaps: Intersections of Race and SED in NAEP Achievement and Instructional Practices Data." Journal of Negro Education 71(4):269-287.

Mamiya, Larry. 2006. "River of Struggle, River of Freedom: Trends Among Black Churches and Black Pastoral Leadership." Pulpit and Pew Research on Pastoral Leadership. Retrieved 26 January 2013 (http://pulpitandpew.org/sites/all/themes/pulpitandpew/files/DUP\&PBlackTrendsWEB finPB!.pdf).

Marsden, George. 1991. Understanding Evangelicalism and Fundamentalism. Grand Rapids: W.B. Eerdmans.

Mulkay, Michael. 1997. The Embryo Research Debate: Science and the Politics of Reproduction. Cambridge, UK: Cambridge University Press.

Paul, Diane B. 1998. Controlling Human Heredity: 1865 to the Present. Amherst, NY: Humanity Books. 


\section{SCIENCE EDUCATION AND EVANGELICALS}

The Pew Forum on Religion and Public Life. 2008. "U.S. Religious Landscape Survey."

Retrieved 8 October 2012 (http://religions.pewforum.org).

The Pew Forum on Religion and Public Life. 2009. "A Religious Portrait of African Americans."

Retrieved June 30, 2014 (http://www.pewforum.org/2009/01/30/a-religious-portrait-ofafrican-americans/)

The Pew Forum on Religion and Public Life. 2010. "Religion Among the Millennials." Retrieved February 7, 2013 (http://www.pewforum.org/Age/Religion-Among-theMillennials.aspx).

Plutzer, Eric and Michael Berkman. 2008. “The Polls-Trends: Evolution, Creationism, and the Teaching of Human Origins in Schools.” Public Opinion Quarterly 72(3):540-553.

Portraits of American Life Study. 2006. "Results and Summaries.” Retrieved June 30, 2014 (http://www.thearda.com/pals/codebook/analysis/Var116.asp)

Scheitle, Christopher P. 2011a. "Religious and Spiritual Change in College: Assessing the Effect of Science Education.” Sociology of Education 84(2):122-136.

Scheitle, Christopher P. 2011b. 'U.S. College Students' Perception of Religion and Science:

Conflict, Collaboration, or Independence? A Research Note.” Journal for the Scientific Study of Religion 50(1):175-186.

Shelton, Jason E. and Michael O. Emerson. 2012. Blacks and Whites in Christian America: How Racial Discrimination Shapes Religious Convictions. New York: New York University Press.

Sherkat, Darren. 2011. "Religion and Scientific Literacy in the United States." Social Science Quarterly 92(5):1134-1150. 


\section{SCIENCE EDUCATION AND EVANGELICALS}

Sherkat, Darren E., and Alfred Darnell. 1999. “The Effect of Parents' Fundamentalism on Children's Educational Attainment: Examining Differences by Gender and Children's Fundamentalism.” Journal for the Scientific Study of Religion 38(1):23-35.

Smidt, Corwin. 2013. American Evangelicals Today. Lanham, MD: Rowman \& Littlefield Publishers.

Smith, Christian, Michael O. Emerson, Sally Gallagher, Paul Kennedy, and David Sikkink. 1998. American Evangelicalism: Embattled and Thriving. Chicago: University of Chicago Press.

Steensland, Brian, Jerry Z. Park, Mark D. Regnerus, Lynn D. Robinson, W. Bradford Wilcox, and Robert D. Woodberry. 2000. "The Measure of American Religion: Toward Improving the State of the Art." Social Forces 79(1):291-318.

Thomas, W.I. and D.S. Thomas. 1928. The child in America. Oxford, England: Knopf.

Thumma, Scott. 2001. "Megachurches Today 2000.” Hartford Institute for Religion Research. Retrieved 31 January 2013 (http://hirr.hartsem.edu/org/faith_megachurches_FACTsummary.html).

United States Census Bureau. 2010. http://factfinder2.census.gov/faces/nav/jsf/pages/index.xhtml. Accessed June 30, 2014.

Woodberry, Robert D., Jerry Z. Park, Lyman A. Kellstedt, Mark D. Regnerus, and Brian Steensland. 2012. "The Measure of American Religious Traditions: Theoretical and Measurement Considerations." Social Forces 91(1):65-73. 